\title{
Can we use neutrophil lymphocyte ratio and platelet lymphocyte ratio as a potential biomarker for acute cholecystitis?
}

\section{Nötrofil lenfosit oranı ve platelet lenfosit oranını akut kolesistit için potansiyel bir biyobelirteç olarak kullanabilir miyiz?}

\author{
Cihan Bedel ${ }^{1 *}$ \\ ${ }^{1}$ University of Health Sciences, Antalya Training and Research Hospital, Department of Emergency Medicine, Antalya, Turkey \\ * Corresponding author: Cihan Bedel E-mail: cihanbedel@hotmail.com ORCID: 0000-0002-3823-2929 \\ Received: 29 December 2018 Accepted: 18 May 2019
}

\begin{abstract}
Aim: The aim of this study is to determine the effectiveness of the neutrophil lymphocyte ratio (NLR) and platelet lymphocyte ratio (PLR) in the diagnosis of acute cholecystitis (AC).

Material and method: 452 patients diagnosed with AC and 152 patients who admitted to the clinic with biliary colic and elective cholecystectomy have been included this study. Groups compared according to age, gender, white blood cell count (WBC), mean platelet volume (MPV), platelet distribution width (PDW), red blood cell distribution width (RDW), NLR and PLR.

Results: There was no significant difference in age between the two groups $(p=0.52)$. Female patients were significantly higher in both control and AC groups ( $p=0.006$ ). WBC, CRP, NLR, PLR values of the patients in the study group have been observed significantly higher than the control group $(p<0.001)$. The parameter with the highest sensitivity and specificity was found as NLR.
\end{abstract}

Conclusions: NLR and PLR can be considered as a potential inflammatory biomarker for AC, due it being inexpensive and easy calculated.

Keywords: acute cholecystitis, neutrophil lymphocyte ratio, platelet lymphocyte ratio 


\section{ÖZ}

Amaç: Bu çalışmanın amacı, akut kolesistit (AK) tanısında nötrofil lenfosit oranı (NLO) ve trombosit lenfosit oranının (PLO) etkinliğini belirlemektir.

Gereç ve Yöntem: Çalışmaya AK tanısı alan 452 hasta ve biliyer kolik ile kliniğe başvuran ve elektif kolesistektomi yapılan 152 hasta dahil edildi. Gruplar yaş, cinsiyet, beyaz kan hücre sayısı (WBC), ortalama trombosit hacmi (MPV), trombosit dağılım genişliği (PDW), kırmızı kan hücre dağılım genişliği (RDW), NLO ve PLO'ya göre karşılaştırıldı.

Bulgular: İki grup arasında yaş açısından anlamlı fark yoktu $(p=0,52)$. Kadın hastalar hem kontrol hem de AK grubunda anlamlı derecede yüksekti $(p=0,006)$. Çalışma grubundaki hastaların WBC, CRP, NLO, PLO değerleri kontrol grubundan anlamlı olarak yüksek bulundu $(p<0,001)$. Hassasiyeti ve özgüllüğü en yüksek olan parametre NLO olarak bulundu.

Sonuçlar: NLO ve PLO, ucuz ve hesaplamasının kolay olmasıyla AK için potansiyel bir inflamatuar biyobelirteç olarak kabul edilebilir.

Anahtar kelimeler: akut kolesistit, nötrofil lenfosit oranı, trombosit lenfosit oranı

\section{INTRODUCTION}

Acute cholecystitis (AC) is one of the most common causes of patients presenting with abdominal pain to the emergency department (ED) [1]. About $90 \%$ of patients, inflammation of the biliary system occurs due to obstruction of the bile duct by gallstones [2]. Delayed management may lead the aggravation to severe cholecystitis situations that increases morbidity such as gangrenous changes, perforation, etc. [3]. The Tokyo Guidelines (TG 18), which include criteria that are classified as clinical markers and ultrasonography (USG) findings of inflammation, are often used for diagnosis [4]. The gold standard diagnostic method for AC is USG. However, USG may not always be available, therefore useful bedside tests are required $[5,6]$.

Recently, neutrophil lymphocyte ratio (NLR) and platelet lymphocyte ratio (PLR) have been proposed as a biomarker for systemic inflammation and thrombotic events. An increased NLR and PLR have been associated with various diseases such as acute appendicitis, myocardial infarction, malignancies [7-9]. However, there is a limited study with NLR and PLR evaluated for patients with AC.

Therefore, the aim of the study is to investigate the diagnostic value of NLR and PLR, especially in patients with AC.

\section{MATERIAL AND METHOD}

In this retrospective study, all procedures were performed according to Helsinki declaration. A total of 604 patients who present ED between January 2017 and November 2018 with complaints of right upper quadrant pain were enrolled. Patients with incomplete medical records, known hematological, autoimmune, neoplastic, liver or renal failure, allergic disease, patients with use of immune suppressive medicines were excluded from this study. Patients were divided into two subgroups: $A C$ and control. The diagnosis of $A C$ was made according to the criteria of the TG $[4,10]$.

Total of 452 patients have been detected from patient records who diagnosed as AC. For the control group, 152 patients were evaluated, who admitted to the clinic with biliary colic and elective cholecystectomy were performed. Blood samples were obtained within 1 hour of the patient's application for ED. After the subgroups were formed, white blood cell (WBC), platelet distribution width (PDW), red cell distribution width (RDW), C-reactive protein (CRP) and mean platelet volume (MPV) were evaluated. The NLR and PLR values were calculated from complete blood count parameters.

\section{Statistical Analysis}

SPSS analysis was performed using SPSS software (version 18.0; SPSS Inc., Chicago, IL, USA). Mean and standard deviations of the parameters were given. Categorical variables were compared using chi-square test and continuous variables using independent $t$ test. In order to define the optimal cut-offs of CRP, NLR, PLR and WBC, Receiver Operating Characteristic (ROC) curve analysis was performed, for which specificities, sensitivities, positive predictive values (PPV) and negative predictive values (NPV) were calculated. $P$ values less than 0.05 were considered statistically significant. 
Table 1. Comparison of groups according to age, gender and laboratory datas

\begin{tabular}{|c|c|c|c|}
\hline Parameter & Acute cholecystitis & Control & p value \\
\hline Age (years; mean \pm SD) & $55.97 \pm 17.96$ & $51.14 \pm 16.66$ & 0.52 \\
\hline Gender (M/F;\%) & $208 / 244(46 / 54)$ & $50 / 102(32.9 / 67.1)$ & 0.006 \\
\hline WBC count $\left(10^{3} / \mathrm{mm}^{3} ;\right.$ mean $\left.\pm \mathrm{SD}\right)$ & $11.42 \pm 4.54$ & $8.39 \pm 2.79$ & $<0,001$ \\
\hline Neutrophil count $\left(10^{3} / \mathrm{mm}^{3} ;\right.$ mean $\left.\pm \mathrm{SD}\right)$ & $8.74 \pm 4.40$ & $5.05 \pm 1.99$ & $<0,001$ \\
\hline Lymphocyte count $\left(\times 10^{3} / \mathrm{mm}^{3} ;\right.$ mean $\left.\pm \mathrm{SD}\right)$ & $1.59 \pm 0.94$ & $2.34 \pm 1.07$ & $<0,001$ \\
\hline Platelet count $\left(\times 10^{3} / \mathrm{mm}^{3} ;\right.$ mean $\left.\pm \mathrm{SD}\right)$ & $278.72 \pm 176.19$ & $258.59 \pm 68.12$ & 0.45 \\
\hline PDW (fL; mean \pm SD) & $16.74 \pm 1.12$ & $16.67 \pm 1.03$ & 0.48 \\
\hline MPV (fL; mean \pm SD) & $8.72 \pm 1.30$ & $8.77 \pm 1.07$ & 0.41 \\
\hline RDW (\%; mean \pm SD) & $15.09 \pm 2.33$ & $14.58 \pm 2.05$ & 0.113 \\
\hline PLR & $224.79 \pm 150.63$ & $130.59 \pm 65.63$ & $<0,001$ \\
\hline NLR & $8.06 \pm 7.30$ & $2.66 \pm 2.03$ & $<0,001$ \\
\hline $\mathrm{CRP}(\mathrm{mg} / \mathrm{L} ;$ mean $\pm \mathrm{SD})$ & $66.04 \pm 88.45$ & $15.23 \pm 28.63$ & $<0,001$ \\
\hline
\end{tabular}

MPV: mean platelet volume; NLR: neutrophil-to-lymphocyte ratio; PCT: plateletcrit; PDW: platelet distribution width; PLR: platelet-to-lymphocyte ratio; RDW: Red cell distribution width ;WBC: white blood cell; CRP: C-reactive protein

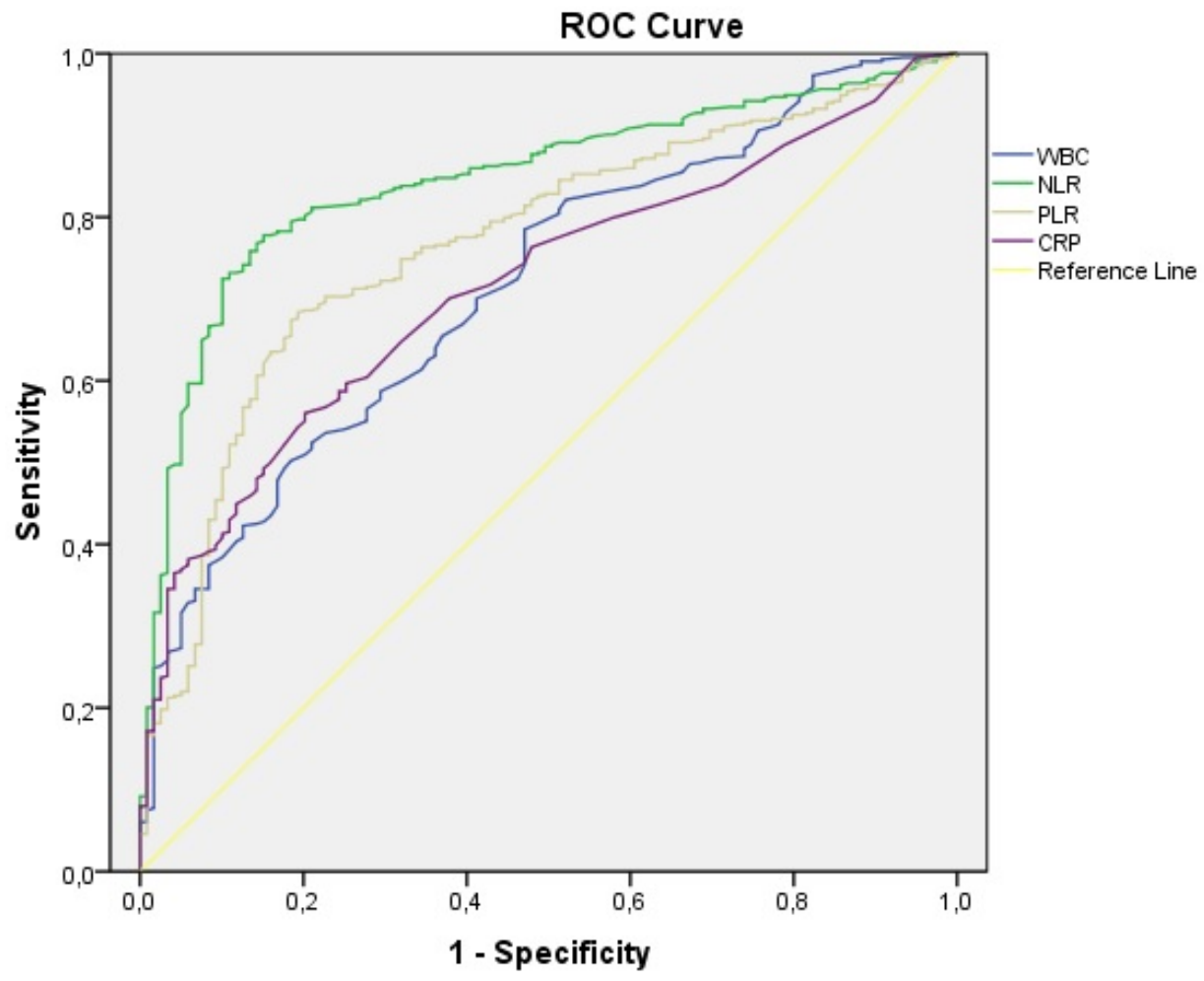

Figure 1. Area under the receiver operating characteristic curve (AUC) for laboratory parameters in the diagnosis of acute cholecystitis. NLR had the highest AUC in predicting AC (AUC $=0.846)$ followed by PLR (AUC $=0.768)$. (WBC: white blood cell; NLR: neutrophillymphocyte ratio; PLR: platelet-lymphocyte ratio; CRP: C-reactive protein)

\section{RESULTS}

A total of 604 patient were included in the study. Of the 604 patients, 436 (57.3\%) were females and 258 (42.7\%) were males. The AC subgroup included 452 patients (74.8\%; 208 males and 244 females), control subgroup included 152 patients (25.2\%; 50 males and 102 females). The mean age of all patients was $54.75 \pm 17.45$ years. There was no statistically significant difference between the mean ages of the subgroups $(p=0.52)$.

The comparison of the $A C$ and control group patients are shown in Table 1. WBC and CRP levels were significantly higher in AC group $(p<0.001)$. There was no significant difference in term of PDW and RDW between two groups ( $p$ $=0.48$ and $p=0.113 ; p>0.05$ respectively). Value of MPV was $8.77 \pm 1.07$ in the control group while it was $8.72 \pm 1.30$ in $A C$ group and the difference was not statistically significant ( $p$ $>0.05$ ). NLR and PLR ratios were found significantly higher in the AC group from the control group $(p<0.05)$.

This study investigated the effectiveness of WBC, NLR, PLR and $C R P$ in prediction of $A C$ using ROC analysis. It was found that the area under curve (AUC) values of these variables were statistically significant to predict AC (Figure 1). NLR 
Table 2. Effectiveness of the parameters in the diagnosis of acute cholecystitis

\begin{tabular}{|c|c|c|c|c|c|c|c|c|}
\hline & AUC & CUT-OFF & SEN (\%) & SPE (\%) & PPV (\%) & NPV (\%) & Accuracy (\%) & P \\
\hline WBC & 0.716 & 8.95 & 66.4 & 72.8 & 66.37 & 61.18 & 65.07 & $<0.001$ \\
\hline CRP & 0.716 & 9.50 & 70 & 73.2 & 64.16 & 70.39 & 65.73 & $<0.001$ \\
\hline NLR & 0.846 & 3.50 & 94.4 & 78.4 & 85.22 & 86.84 & 88.15 & $<0.001$ \\
\hline PLR & 0.768 & 148.13 & 77.9 & 76.2 & 69.26 & 75.22 & 74.14 & $<0.001$ \\
\hline
\end{tabular}

AUC: area under the curve; SEN: sensitivity; SPE: specificity; PPV: positive predictive value; NPV: negative predictive value; WBC: white blood cell; RDW: red cell distribution width; CRP: C-reactive protein; NLR :neutrophil-to-lymphocyte ratio; PLR: platelet-to-lymphocyte ratio

had the highest AUC $(0.846 ; p<0.001)$, followed by PLR, WBC and CRP ( $A U C=0.768,0.716$ and 0.716). Moreover, at a cutoff value of NLR>3.5, the highest sensitivity (94.4\%), specificity (78.4\%), PPV (85.22\%), and NPV (86.84\%) were achieved for prediction of AC in approximately $88.15 \%$ of the cases (Table 2).

\section{DISCUSSION}

This study showed that WBC, NLR, PLR and CRP are useful markers of inflammatory response. Present study reported that NLR and PLR were a significant marker for AC and can be used as an alternative to CRP.

$A C$ is one of the most common inflammatory diseases of gallbladder.

Diagnostic criteria for $A C$ are signs of local or systemic inflammation and imaging findings [11]. Local symptoms of inflammation are right upper quadrant pain, tenderness, and positive Murphy symptoms. Fever, elevated erythrocyte sedimentation rate, CRP and WBC values can be determined as systemic symptoms $[5,12]$. But these laboratory values may have some disadvantages. For example, they may be affected by some non-inflammatory conditions such as age, sex. In addition, CRP may not begin to increase immediately after the onset of symptoms. Due to these limitations, the researchers tend to begin a quest to find a new inflammatory marker such as NLR and PLR.

Several studies showed that NLR can be used the diagnosis of $A C[6,11,13]$. In another study of Lee at al showed that cutoff value of NLR $>3$ is associated with mortality and severity of AC [13]. Ertok et al. showed that NLR was significantly higher in patients with AC. The authors reported that, for a NLR cut-off value of $4.115,75.9 \%$ sensitivity and $77.7 \%$ specificity was detected [6]. In another study with a cut-off value of 3.5 for NLR sensitivity and specificity was found (94.4; 78.4, respectively). In this study, sensitivity and specificity were higher $(75.9 ; 77.7 \%$, respectively). Therefore, NLR was accepted as a significant marker for AC.

Studies reported that PLR can be a useful marker for inflammatory diseases such as acute appendicitis, myocardial infarction $[7,14]$. However, in this study, for a PLR cut-off value of 148.13 , sensitivity and specificity were lower than NLR. Other CBC parameters (PDW, RDW and MPV), sensitivity and specificity were lower than of NLR and PLR. Therefore, these markers were not considered as significant AC markers.

In one study, for a CRP cut-off value of 30.5 , sensitivity and specificity for AC was (85; 92 percent, respectively) [15]. In another study high values of CRP are the predictor of $A C[16]$. In present study, for a CRP cut-off value of 9.5, sensitivity and specificity was (70; 73.2 percent, respectively). Therefore, CRP is generally considered to be a good infection marker. In this study, sensitivity and specificity for AC detection were lower compared to NLR and PLR.

As a result, NLR and PLR can be considered as a potential inflammatory biomarker for $A C$, due it being inexpensive and easy calculated.

\section{DECLARATION OF CONFLICT OF INTEREST}

The authors received no financial support for the research and/or authorship of this article. There is no conflict of interest.

\section{REFERENCES}

1. Beliaev AM, Angelo N, Booth M, Bergin C. Evaluation of neutrophil-to-lymphocyte ratio as a potential biomarker for acute cholecystitis. J Surg Res 2017;209:93-101.

2. Hareen TK, Bhaskaran A, Jaswanthi A. Neutrophil to lymphocyte ratio in diagnosing acute cholecystitis: a retrospective cohort study in a tertiary rural hospital. Int J Surg 2016;4(1):372-6.

3. Joliat GR, Longchamp G, Du Pasquier C, Denys A, Demartines N, Melloul E. Delayed Cholecystectomy for Acute Cholecystitis in Elderly Patients Treated Primarily with Antibiotics or Percutaneous Drainage of the Gallbladder. J Laparoendosc Adv Surg Tech A 2018;28:1094-1099.

4. Miura F, Okamoto K, Takada T, et al. Tokyo Guidelines 2018: initial management of acute biliary infection and flowchart for acute cholangitis. J Hepatobiliary Pancreat Sci 2018;25:31-40. 
5. Sayit AT, Gunbey PH, Terzi Y. Is the mean platelet volume in patients with acute cholecystitis an inflammatory marker? J Clin Diagn Res 2015;9:5-7.

6. Ertok I, Karakayalı O, Kocasaban DU. Clinical Importance Of Neutrophil/Lymphocyte Ratio In Differential Diagnosis Of Acute Cholecystitis And Cholelithiasis. Kocaeli Med J 2016;5:6-11.

7. Bedel C. Diagnostic value of basic laboratory parameters for simple and perforated acute appendicitis. Turk J Clin Lab 2018;4:266-71.

8. Sheng F, Chen B, He M, Zhang M, Shen G. Neutrophil to lymphocyte ratio is related to electrocardiographic sign of spontaneous reperfusion in patients with ST-segment elevation myocardial infarction. Arch Med Res 2016;47:180-5.

9. Goh BK, Chok AY, Allen Jr JC, et al. Blood neutrophil-tolymphocyte and platelet-to-lymphocyte ratios are independent prognostic factors for surgically resected gastrointestinal stromal tumors. Surgery 2016;159:114656.

10. Kiriyama S, Takada T, Strasberg SM, et al. TG13 guidelines for diagnosis and severity grading of acute cholangitis (with videos). J Hepatobiliary Pancreat Sci 2013;20:24-34.
11. Temizi A, Ozdemir Y, Aslan A, Bostanci MT, Atasoy G, Caparlar MA, et al. Role of complete blood counts parameters in diagnosıs of acute cholecystıtıs. Acta Med Mediterr 2017;33(3):411-6.

12. Barbosa ABR, Souza LRMFd, Pereira RS, D'Ippolito G. Gallbladder wall thickening at ultrasonography: how to interpret it? Radiol Bras 2011;44:381-7.

13. Lee SK, Lee SC, Park JW, Kim S-J. The utility of the preoperative neutrophil-to-lymphocyte ratio in predicting severe cholecystitis: a retrospective cohort study. BMC Surg 2014;14:100.

14. Temiz A, Gazi E, Güngör O, et al. Platelet/lymphocyte ratio and risk of in-hospital mortality in patients with STelevated myocardial infarction. Med Sci Monit. 2014;20:660-5.

15. Beliaev AM, Marshall RJ, Booth M. C-reactive protein has a better discriminative power than white cell count in the diagnosis of acute cholecystitis. J Surg Res 2015;198:6672.

16. Başol N, Çığşar G, Karaman S, Özsoy Z, Özdemir MB. The evaluation of patients with acute cholecystitis in the Emergency Department according to neutrophillymphocyte ratio and epidemiological factors: threeyears analysis. İstanbul Bilim University Florence Nightingale Med J 2015;1:145-9 